\author{
Luiza Wieczorek \\ ORCID 0000-0002-5843-099X \\ Institute of Earth Science, Department of Meteorology and Climatology \\ wieczorek-luiza@o2.pl \\ Wiktor Piech \\ ORCID 0000-0001-5068-1631 \\ University of Lodz \\ Institute of Earth Science, Department of Geomorphology and Palaeogeography \\ wiktor.piech@geo.uni.lodz.pl \\ Bartłomiej Cybulski \\ ORCID 0000-0002-9529-1976 \\ Mateusz Kujawiński \\ ORCID 0000-0002-0313-2776 \\ Agnieszka Wegierska \\ ORCID 0000-0001-9128-259X \\ Lodz University of Technology \\ Institute of Automatic Control \\ bkcybulski@gmail.com,mateusz.kujawinski.92@gmail.com,wegierska.agnieszka@gmail.com
}

\title{
PARTICIPATION IN INTERNATIONAL ROBOTICS COMPETITIONS AS A NEW FORM OF STUDENT TRAVEL
}

\begin{abstract}
The article presents opportunities for foreign travel by students based on trips to international competitions, in particular robotic competitions. As the data collected show, these have attracted several thousand participants in recent years. The article presents an additional effect of participation in such competitions which is tourism during the trips.
\end{abstract}

Keywords: competition tourism, United States, students, mars rover.

\section{INTRODUCTION}

The second half of the $20^{\text {th }}$ century and the present $21^{\text {st }}$ century is a time of expansion in space research. Former hoped-for plans for the exploration of the solar system have become real. Despite technological advances however, unmanned missions dominate over manned. The vision of space tourism, so longed for, is slowly beginning to develop (RÓŻYCKI, WYSOCZYŃSKA 2011, RÓŻYCKI, KRUCZEK 2017). With regard to unmanned, the leading missions involve the use of the so-called 'rovers' which are robots that can move on the surface of where they land. Until now, missions to the Moon and Mars have been successfully carried out. This article will present the tourist aspect related to the second group of rovers. As it turns out, they have a significant impact on tourism connected with robot competitions all over the world. Very often participation in such a competition is the only chance for long-distance travel among students from different countries, especially India or Bangladesh. On the other hand, thanks to this type of competition, local tourism gains benefits. Small towns, which become accommodation bases for incoming participants, achieve an income high above the seasonal average.

The benefits in this case are mutual, students broaden their horizons in the area of tourism and science, while the town that hosts the competition achieves higher revenues. This article will present the most popular robotic competitions, a description of participants in terms of representation from given countries, as well as correlation with a state's policy on incoming travel. The analysis will cover the development of travel opportunities and associated tourism activities with regard to the participation of students. The competitions of the University Rover Challenge and the European Rover Challenge will be described later in the article as case studies. The database was created by the authors mainly on the basis of compilations and statistics posted on the websites of the competition organizers. Detail was obtained by the method of in-depth interviews with members of one Polish team participating in these competitions. 


\section{TRAVEL AMONG STUDENTS}

The travel motif has accompanied students for centuries. Depending on history, these journeys have taken various forms. In ancient times, students were able to travel hundreds of kilometers to learn from contemporary mentors in a given area of life. It was similar in the Middle Ages when universities started to emerge and future students left their homeland and went to selected universities in distant parts of Europe to gain valuable and, otherwise, inaccessible knowledge. The $21^{\text {st }}$ century has brought new migration trends and currently, it is not only trips that give an opportunity to study at foreign universities. Since 2004, the share of foreign students in particular European countries has been steadily growing (the largest increases concern the Netherlands, Denmark, Spain, Poland, the Czech Republic and Belgium). Among the visitors, the largest groups are students from China, Saudi Arabia and Vietnam (OKÓLSKI 2017). From a global perspective, the majority of foreign students select the United States, Great Britain and Australia - meaning the English-speaking countries which dominate here (HUT, JAROSZEWSKA 2011). Foreign students in 2009 went most often to Europe (46\%), then North America (23\%) and Asia (11\%).

H. VARASTEH, A. MARZUKI \& S.M. RASOOLIMANESH (2014) analyzed factors that influenced student travel behavior. According to them, elements such as age, marital status and nationality are of decisive importance. The least important elements are gender, university, completed internships, or length of travel. An important issue is access to information posted at the home universities. Some students decide about their chosen destination only after talking with their peers who have already had the opportunity to do similar trips abroad. The preferred destinations are trips to national parks, to festivals, or to museums (MICHAEL, ARMSTRONG \& KING 2003).

The increase in migration by students from around the world it is not only caused by travelling to foreign research centers as part of student exchanges or internship programs in international corporations. With the development of new technologies, new opportunities for foreign trips are created and their number is steadily growing every year. Participants in competitions agree that it is a great opportunity to test their ideas and is a factor driving the development of new technologies as well as another chance for a foreign trip for a wider group of students. In connection with this one type should be specified, namely student travel as a part of robotics competitions.

\section{METHODS AND DATABASE}

For the purposes of this study, a comprehensive database containing descriptions of 278 teams from a dozen or so countries was built. Data concern the last eleven years, in the case of the University Rover Challenge, and three years for the European Rover Challenge. For this purpose, the competition lists posted on the websites of the organizers were used. Moreover, the websites run by individual teams from around the world, and the funpages of teams on social media, were a source of data. In order to fill in any gaps, e-mail contact with teams and contest organizers was maintained. The database was pre-pared in tabular form with the following elements: number of applications and finalists in particular years, descriptions of teams, results of competitions, and visa policies. Due to limited access (protection of personal data), the number of people in a given team was estimated through analysis of information contained in the other sources.

Analysis of the tourist aspect of student travel was carried out on the basis of information obtained through the in-depth interviews conducted with members of the Raptors team from Łódź (10 interviews). Thanks to this method, accurate and detailed information on the financing, accommodation preferences, means of transport and aspects of tourism used by Raptors' team members was obtained. Other information on local tourist attractions has been supplemented on the basis of foreign websites and tourist guidebooks. In turn, data on the accommodation base has been supplemented through the booking.com website. The content of the article is complemented with photographs and figures adapted to the subject.

\section{CHARACTERISTICS OF ROBOTIC COMPETITIONS}

The development of robotics has increased the number of robotic competitions dedicated for students of all $\mathrm{HE}$ institutions, research laboratories and professional companies. The rivalry has meant that more and more technologically advanced constructions are reported in each subsequent competition. The attractiveness of some competitions is raised by high cash prizes which allow the distinguished teams to purchase new equipment. This article will discuss some robotic competitions (Table 1) for students during which teams can verify their constructions in a real environment. 
Table 1. List of robotics competitions

\begin{tabular}{|c|c|c|c|c|}
\hline POS & Competition name & Logotype & Country & Characteristics of competition \\
\hline 1 & $\begin{array}{l}\text { University Rover } \\
\text { Challenge } \\
\text { (URC) }\end{array}$ & & USA & $\begin{array}{c}\text { Martian rover competition for teams consisting of at least half } \\
\text { undergraduate and graduate students } \\
\text { (https://en.wikipedia.org/wiki/Mars_Society). }\end{array}$ \\
\hline 2 & $\begin{array}{l}\text { European Rover } \\
\text { Challenge } \\
\text { (ERC) }\end{array}$ & & Poland & $\begin{array}{l}\text { Similar to URC. Since } 2018 \text { a new category has been introduced } \\
\text { for professionals in which, for example companies and } \\
\text { research laboratories, can participate } \\
\text { (http:// roverchallenge.eu/pl/o-erc/). }\end{array}$ \\
\hline 3 & $\begin{array}{c}\text { Canadian } \\
\text { International Rover } \\
\text { Challenge (CIRC) }\end{array}$ & & Canada & \multirow{2}{*}{$\begin{array}{l}\text { Competitions for students focused on the development } \\
\text { of technology and space solutions } \\
\text { (https:// circ.cstag.ca/about/, } \\
\text { https:// www.mbzirc.com/). }\end{array}$} \\
\hline 4 & $\begin{array}{l}\text { Indian Rover } \\
\text { Challenge (IRC) }\end{array}$ & & India & \\
\hline 5 & $\begin{array}{l}\text { Mohamed Bin } \\
\text { Zayed International } \\
\text { Robotics Challenge } \\
\text { (MBZIRC) }\end{array}$ & М|DदीFS & $\begin{array}{c}\text { United Arab } \\
\text { Emirates }\end{array}$ & $\begin{array}{l}\text { Competition dedicated to land and aerial robots oriented to } \\
\text { developing autonomy and advanced technology } \\
\text { (https://www.mbzirc.com/). }\end{array}$ \\
\hline 6 & $\begin{array}{l}\text { World Robot } \\
\text { Summit } \\
\text { (WRS) }\end{array}$ & World Robot Summit & Japan & $\begin{array}{c}\text { Competition of inspection, search and rescue, service robots } \\
\text { connected with a trade show of the technology } \\
\text { (http:/ / worldrobotsummit.org/en/). }\end{array}$ \\
\hline 7 & $\begin{array}{l}\text { ERL Emergency } \\
\text { Service Robots }\end{array}$ & $\begin{array}{l}\text { EUROPEAN } \\
\text { ROBOTICS } \\
\text { LEAGUE } \\
\text { Brought to you by SPARC }\end{array}$ & Italy, Spain & $\begin{array}{l}\text { Competition for heterogeneous mobile robots carrying out } \\
\text { search and rescue activities dedicated to teams consisting of } \\
\text { students, research laboratories and companies } \\
\text { (https:// www.eu-robotics.net/robotics_league/about/the- } \\
\text { european-robotics-league/index.html). }\end{array}$ \\
\hline
\end{tabular}

Source: authors' compilation.

Tasks concern real problems in which robotics are applied, for example exploration of distant planets, inspection and emergency action. Student competitions allow new contacts to be made and information to be exchanged between students from different universities around the world.

Two the most important competitions in the field of robotics (URC and ERC) are organized by the Mars Society (Fig. 1). This society is the biggest in the world and aimed at the settlement and exploration of Mars, and was founded by Robert Zubrin in 1998. It works on the education of society, media and governments about the benefits of colonizing Mars and the future settlement of the red planet. For scientific needs they have created two research stations which simulate the Martian environment. The first one (Flashline Mars Arctic Research Station - FMARS) is placed on Devon Island in the Canadian Arctic and the second (Mars Desert Research Station - MDRS) is located near Hanksville in the US state of Utah (https://en.wiki pedia.org / wiki/Mars_Society).

\section{IHE MARS SOCIETY6}

Fig. 1. Logotype of The Mars Society
Each year at the turn of May and June (since 2007), MDRS changes into a maneuvering field for Mars rovers constructed by students from around the world. For three days the largest, most well-known and prestigious competition - the University Rover Challenge - is held here. Teams struggle with tasks related to the exploration and examination of the area, transportation and autonomous driving. During a task, rover operators are located in a base station, and to control their rover they use only data from sensors and cameras so they are in a similar situation to operators of Martian rovers during real missions (http:// urc.marssociety.org/).

The younger international competition taking place on the continent of Europe, is the European Rover Challenge which is held in Poland in 2014, 2015, 2016 and 2018. The ERC allows progress in the development and implementation of new technologies to be verified by students from around the world. The tasks are similar to those during the URC and concern e.g. team presentation or gathering soil samples for later physiochemical analysis. The rank of the competition is confirmed by the arrival international guests connected with astronautics, automation and robotics and a visit by the Mars Society founder, Robert Zubrin (http:// roverchallenge.eu/pl/o-erc/). 
The Mars Society also organizes CIRC - Canadian International Rover Challenge and the Indian Rover Challenge whose tasks are similar. The Canadian International Rover Challenge takes place in July (from 2017) in Drumheller in Canada (https:/ / circ.cstag.ca/ about/) while the Indian Rover Challenge takes place at the beginning of January at the Manipal Institute of Technology. This competition limits the weight and cost of robots which allows less well-funded teams to compete (https:/ / www.indianroverchallenge.in/).

Another center of robotics research is the United Arab Emirates where every two years the Mohamed Bin Zayed International Robotics Challenge competition is held. It is a relatively young competition because the first one took place in 2017. The rules of qualification are very demanding and finally, in 2017, 25 teams were selected and competed in tasks related to land and aerial robots. Tasks were oriented to develop autonomous systems to control unmanned vehicles that can recognize and track objects, move on different terrains and make decisions on their own (https:// www.mbzirc.com/).

Japan has a significant position in the development of robotics. In November 2018 the World Robot Challenge took place in Tokyo - competition combined with a trade show of technology called World Robot Summit 2018. For student teams this event is a great opportunity to become familiar with new technologies available on the market and allows familiarization with the requirements currently imposed on robots. One of the tasks is related to inspection and rescue actions in a simulated industrial plant while a goal of the competition is to prepare the organizers and competitors for the next competition, which will take place in 2020 in Fukushima (http://worldrobotsum mit.org/en/).

Emergency Service Robots (ERL), organized by the European Robotics League since 2016, deserves attention. The participants are not only student teams but also research laboratories and companies and during the event teams work on tasks simulating a real crisis situation, for example a tsunami. Organizers pay attention to the cooperation of heterogeneous mobile robots during common search and rescue missions simultaneously taking place under water, on land and in the air (https://www.eu-robotics.net/robotics_lea gue/about/the-european-robotics-league/index.html).

\section{RESULTS DISCUSSION}

Students from 16 countries take part in the ERC and URC competitions from Bangladesh, Egypt, Spain, the Netherlands, India, Canada, Colombia, South Korea, Mexico, Nepal, Poland, Turkey, the United States,
Great Britain, Italy and Australia (Fig. 2). The database contains details competitions from 2007 (URC) and from 2014 (ERC). The United States and Poland have the biggest number of representatives in robotic competitions followed by India, Canada and Bangladesh. The remaining countries have single representations (Fig. 1).

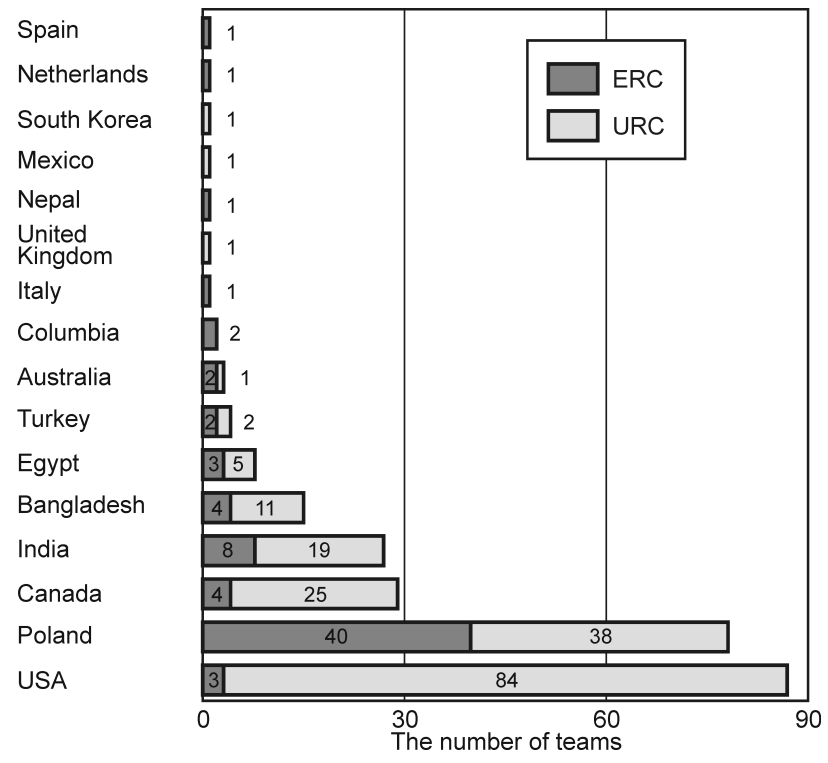

Fig. 2. The number of teams from individual countries in all URC and ERC competitions Source: http:/ / urc.marssociety.org/, http:/ / roverchallenge.eu/pl/home/

Student travel, as part of competitions (not only from the robotics sector), is strongly influenced by constantly changing political conditions. According to the two analyzed here, US visa policy has had an enormous impact and its consequences are presented in table below (Table 2).

Table 2. Visa situations in the countries involved in URC and ERC

\begin{tabular}{|l|l|}
\hline \multicolumn{1}{|c|}{$\begin{array}{c}\text { A visa-free regime } \\
\text { (Visa Waiver Program) }\end{array}$} & \multicolumn{1}{c|}{ Need for a visa } \\
\hline Australia & Bangladesh \\
\hline Spain & Egypt \\
\hline Netherlands & India \\
\hline South Korea & Columbia \\
\hline United Kingdom & Mexico \\
\hline Italy & Nepal \\
\hline $\begin{array}{l}\text { Canada (separate } \\
\text { arrangements) }\end{array}$ & $\begin{array}{l}\text { Poland (country nominated } \\
\text { for the visa-free program) }\end{array}$ \\
\hline & $\begin{array}{l}\text { Turkey (country nominated } \\
\text { for the visa-free program) }\end{array}$ \\
\hline
\end{tabular}

Source: https://pl.usembassy.gov//.

It is easy to notice that three (Poland, India, Bangladesh) of the five most-represented countries have an obligation for a visa to visit the United States. This is 
an additional financial burden for students and a need to meet the administrative requirements. Failure to meet the visa requirements results in not being allowed to enter the US - and thus blocking participation in the URC competition. In the case of the ERC, it is much easier to have teams from Europe in which the EU's migration rules apply while other countries are required to apply for visas for students which will allow them to stay in Poland.

Analyzing the number of participants, a continual increase in the number of teams in both URC and ERC competitions is found (Fig. $3 \& 4$ ). The reasons for the growing openness to foreign ideas are that the international exchange of thoughts, ideas and conceptions have a significant impact. Both competitions consist of home country eliminations leading to travel to a final competition in which there is a fixed number of teams.

Teams in both URC and ERC included an average of about 12 members (Table 3) with males predominating over females, most often three times as many, and there are specific cases in which a team consists only of males. Most probably, this is due to the fact that the universities from which students come, are technical universities dominated by men. An example are the technical universities in Poland where the proportion of females is $36.8 \%$ (Szkoty wyzsze... 2016). Students who take part in competitions usually study automation and robotics, electrical engineering, mechatronics, mechanics and machine building, or computer science. The proportion of females here is very low: e.g. automation and robotics

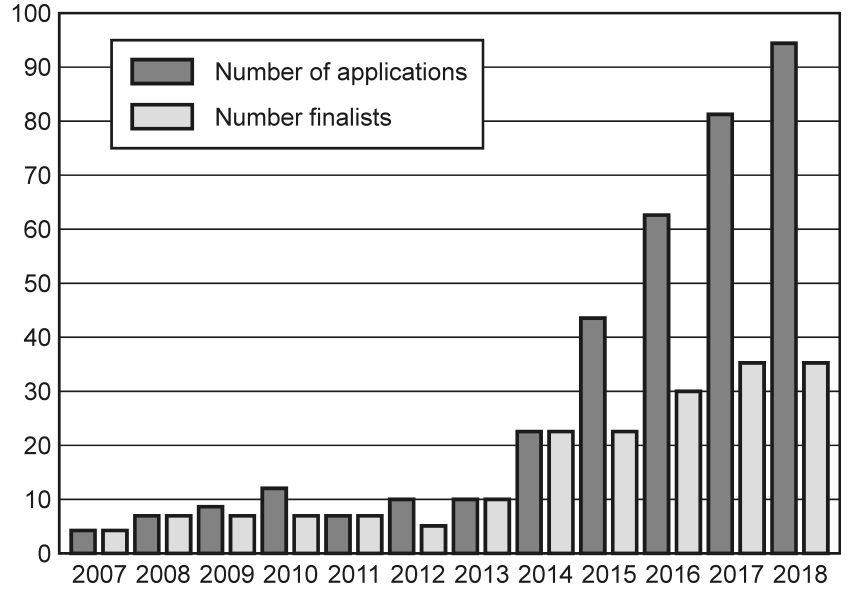

Fig. 3. Number of applications and finalists in the URC competition in individual years Source: http://urc.marssociety.org

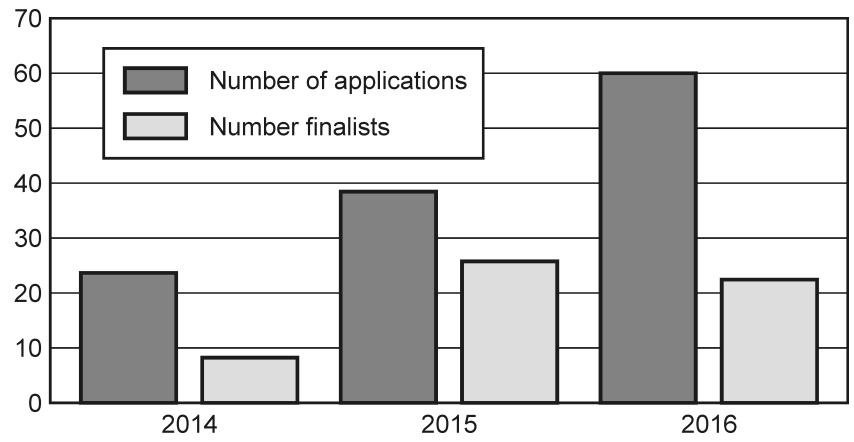

Fig. 4. Number of applications and finalists in the ERC competition in individual years

Source: http:/ / roverchallenge.eu/en/home/

Table 3. Estimated number of participants from individual participating countries in the URC and ERC

\begin{tabular}{|c|c|c|c|c|c|c|c|c|}
\hline \multirow{4}{*}{ Country } & \multirow{2}{*}{\multicolumn{2}{|c|}{$\begin{array}{c}\text { Participation of teams } \\
\text { in all years }\end{array}$}} & \multicolumn{6}{|c|}{ The sum in teams assuming } \\
\hline & & & \multicolumn{2}{|c|}{$\begin{array}{l}\text { a minimum } \\
\text { (6 people) }\end{array}$} & \multicolumn{2}{|c|}{$\begin{array}{c}\text { a maximum } \\
\text { (20 people) }\end{array}$} & \multicolumn{2}{|c|}{$\begin{array}{l}\text { an average } \\
\text { (12 people) }\end{array}$} \\
\hline & \multicolumn{8}{|c|}{ name of the competition } \\
\hline & ERC & URC & ERC & URC & ERC & URC & ERC & URC \\
\hline Australia & 2 & 1 & 12 & 6 & 40 & 20 & 24 & 12 \\
\hline Bangladesh & 4 & 13 & 24 & 78 & 80 & 260 & 48 & 156 \\
\hline Egypt & 3 & 5 & 18 & 30 & 60 & 100 & 36 & 60 \\
\hline Spain & 1 & 0 & 6 & 0 & 20 & 0 & 12 & 0 \\
\hline Netherlands & 1 & 0 & 6 & 0 & 20 & 0 & 12 & 0 \\
\hline India & 8 & 19 & 48 & 114 & 160 & 380 & 96 & 228 \\
\hline Canada & 4 & 25 & 24 & 150 & 80 & 500 & 48 & 300 \\
\hline Columbia & 2 & 0 & 12 & 0 & 40 & 0 & 24 & 0 \\
\hline South Korea & 0 & 1 & 0 & 6 & 0 & 20 & 0 & 12 \\
\hline Mexico & 0 & 1 & 0 & 6 & 0 & 20 & 0 & 12 \\
\hline Nepal & 1 & 0 & 6 & 0 & 20 & 0 & 12 & 0 \\
\hline Poland & 40 & 38 & 240 & 228 & 800 & 760 & 480 & 456 \\
\hline Turkey & 2 & 2 & 12 & 12 & 40 & 40 & 24 & 24 \\
\hline USA & 3 & 84 & 18 & 504 & 60 & 1680 & 36 & 1008 \\
\hline United Kingdom & 0 & 1 & 0 & 6 & 0 & 20 & 0 & 12 \\
\hline Italy & 1 & 0 & 6 & 0 & 20 & 0 & 12 & 0 \\
\hline
\end{tabular}

Source: http:/ / urc.marssociety.org, http:/ / roverchallenge.eu; own research. 
(9.1\%), electrical engineering (6\%), mechatronics (8.3\%), mechanics and machine building $(8.6 \%)$ and IT $(11.7 \%)$ (Raport... 2017).

As part of the ERC competition from 192 to 640 students (excluding from Poland) from all over the world (average of around 384). Together with Polish students, for whom a trip to such a competition is also a chance for tourism, the figure is from 432 to 1440 (average about 854). Most students came from India (from 48 to 160), the least from Nepal, the Netherlands and Italy (from 6 to 20) (Table 3).

Analyzing the number of students due to a given continent of origin, most people came from Asia (India, Bangladesh, Nepal), from 78 to 260. In this aspect, Europe (with no students from Poland) ranks only third behind North America (Table 3, Fig. 5).

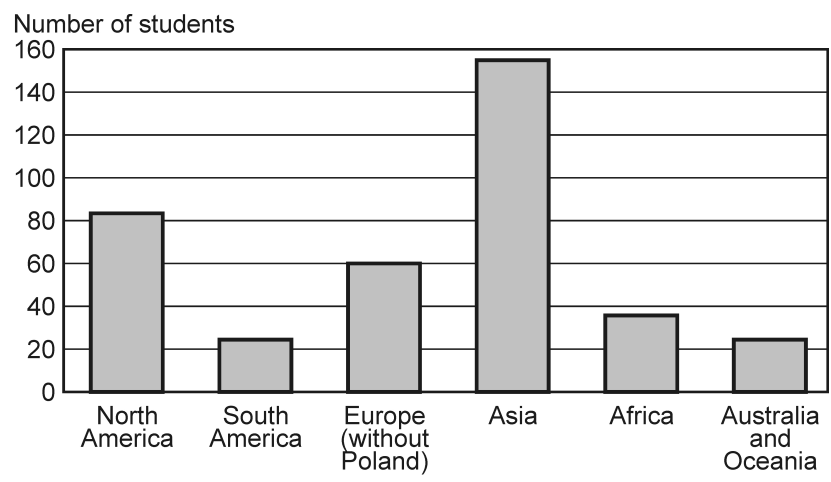

Fig. 5. Average number of students from particular continents in the ERC competition in all years

Source: http:/ / roverchallenge.eu; own research

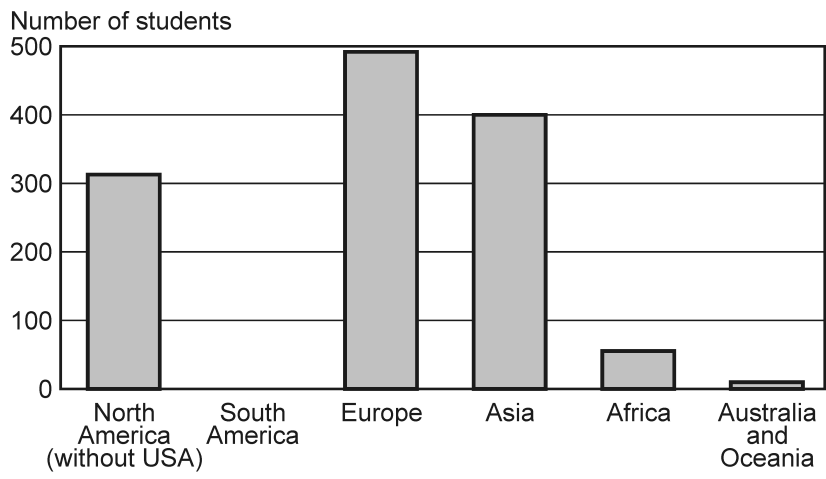

Fig. 6. Average number of students from particular continents in URC competition from the beginning of the competition Source: http:/ / roverchallenge.eu; own research

The number of students who came to the USA (without US students) from different parts of the world is from 636 to 2120 (on average, about 1272). Counting US students, this number increases being from 1140 to 3800 (average - 2280). Most people came from Europe, from 246 to 820 students, of which 92.68\% are students from Poland (Fig. 6). Next are Asia and North America (mainly students from Canada).
Since the beginning there has not been a team from South America. This is most likely caused by a complex system of granting visas for this region of the world.

\section{TOURISM ASPECTS}

Exact information relating to travel on international competition - the University Rover Challenge (URC, USA) and European Rover Challenge (ERC, Poland) - is not possible to determine for all the teams shown in this article. However, at the beginning it should be realized that the main goals are not connected in any way to student travel. The excellent location of the URC in one of the most beautiful places of USA, encourages tourist activities. In this article a case study is based on five years' experience of the Raptors team.

The Raptors team consists of BSc, MSc and PhD students Łódź University of Technology, supported by PhD students from University of Łódź, developing know-how in the field of mobile robotics. The twelve team members work at automatic control, robotics, mechanics, IT, environmental surveys and management. During journeys team members treat tourist activities as a rest from intellectual work.

The journey to the competition is somehow a payoff for the long preparation time and becoming one of the finalists is a reward as preparation has started months before the competition. However, the journey in terms of tourist activities can be divided into finding finance, getting to the competition and the return home.

Finding finance is one of the most important aspects and its level has a major impact on the journey and the number of members who may take part; two facts directly influencing tourist potential. Competition journeys to the USA are long and costly; in Poland they are short and cheap.

To determine the minimum period for a journey, competition length, outward and return travel time and organizational work must be taken into consideration. For teams coming from other countries this last point takes much longer, for instance collecting and dispatching the robot, and its assembly and disassembly. To determine the journey period is an individual issue for each team and depends on available financing and planned tourist activities. Each additional day over the minimum trip length gives a chance for a better journey, work on the rover and being a tourist. From the Raptors team experience, a minimum trip length is 11-12 days. In practice the cost may be divided into fixed costs not affected by journey length, e.g. flight, visa, robot shipping; and variable costs e.g. accommodation, food and car rental. From 
experience the fixed cost for a group of 10 members is around 6,000 $\mathrm{zl}$ and variable costs $350 \mathrm{zl} /$ day. It can be deduced that short trips are not economically viable and even a small extension of time could dramatically improve tourism aspects at only a small extra cost. For example, taking a 12-day journey will cost around $100,000 \mathrm{zl}$, but by extending this period to 18 days (by $50 \%$ ) the cost rises only to $122,000 \mathrm{zl}$ $(22 \%)$. During the additional six days the team are able to visit most of the attractions in Utah, California and Nevada e.g. Grand Canyon, Death Valley, Antelope Canyon and the cities Los Angeles and Las Vegas.

The competition area is located in the central part of the state of Utah. From the point of view the international teams getting to the competition site the large distance from the nearest international airports const- rains activity (he closest are located in Los Angeles, Las Vegas, San Francisco and Denver). The Raptors team always choose Los Angeles which is $1027 \mathrm{~km}$ from competition site. This choice is not accidental and results from better flight options, a good accommodation base, a large number of car rental companies and high tourist potential. In the case of intercontinental trips the team always add some days for processing formalities e.g. car rental. This period also allows acclimatization to the new environment and getting basic knowledge about the area and culture. The route to the competition site is by car, so tourism is obviously a part of it. Among the best attractions seen on the road are Hoover Dam, route 66, Joshua Tree NP, Las Vegas, Bryce Canyon NP, Zion NP.
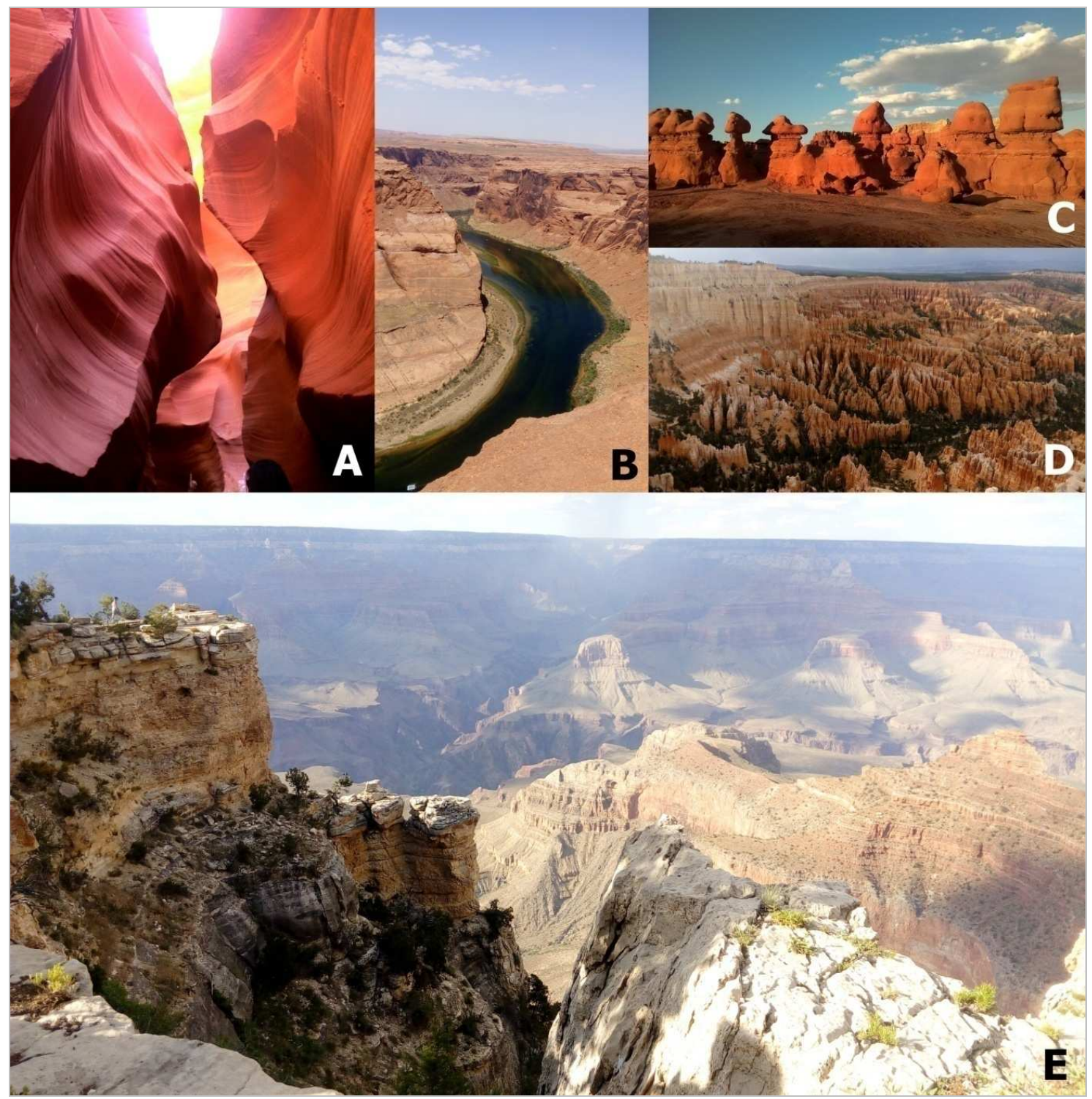

Photo 1. Characteristic points connected with a trip to competition site

A - Antelope Canyon, B - Glen Canyon - Horseshoe Bend, C - Goblin Valley, D - Bryce Canyon, E - Grand Canyon Source: photos A \& C - W. Piech (2017), photos B, D \& E - L. Wieczorek (2017) 
Commonly the trip takes 2-3 days, with a stop in Las Vegas for 1-2 nights. Its population is 641676 and it is well known from many casinos and world class hotels whose overall room count reached 148690 in 2017 (www.factfinder.census.gov). There are over 1700 licensed gambling sites, and almost 200000 slot machines with most of the casinos on Las Vegas Strip boulevard. Generally, casinos are shared with hotels and the most recognizable are the Luxor in the form of black glass pyramid, Excalibur in the form of fairy castle, MGM Grand with its well-known hall and Cesar's Palace styled on the Roman Empire. Other large casinos are Mandalay Bay, Treasure Island, Monte Carlo, Bellagio and The Mirage. In front of The Mirage hotel a volcanic eruption is performed at sunset every day. The Bellagio is proud of one of the biggest fountains in the world, and shows with music, light and water are performed several times a day. Casino New York-New York is also a very special place on the map of Las Vegas; the whole building is stylized similarly to the architecture seen in New York and in front of the hotel is a roller-coaster. Additionally, in other hotels an Eiffel tower at a scale of 1:2 and an Arc de Triomphe can be seen.

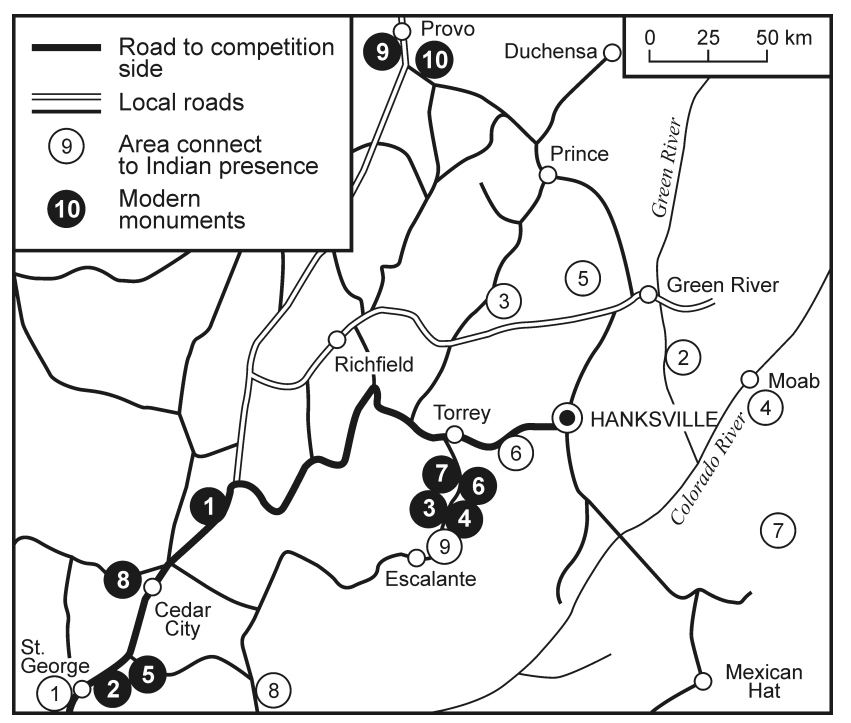

Fig. 7. Monuments and tourist attractions close to the URC competition - Hanksville

1 - road to competition site; 2 - local roads; 3 - area connected to Indian presence (1 - Bloomington Petroglyph Park, 2 - Rochester Rock, 3 - Barrier Canyon (Horseshoe Canyon), 4 - Moab area, 5 - San Rafael Swell, 6 - Capitol Reef, 7 - Mule Canyon Ruins, 8 - Moqui Cave, 9 - Anasazi Indian Village State Park); 4 - modern monuments (1 - Cove Fort, 2 - Brigham Young Winter Home Historical Site, 3 - Gifford Homestead at Capitol Reef, 4 - Fruita, 5 - Jacob Hamblin House, 6 - Behunin Cabin, 7 - Pioneer Register, 8 - Old Iron Town, 9 - Provo City Center Temple, 10 - Brigham Young University)

Source: B. PRETTYMAN (2017), http:/ / utah.com/, http://www.visitutah.com/
The trip to the competition site, in such an organizational scenario, shows that visiting these attractions is only short and superficial but enough time to see some key features and the most famous places (Photos 1).

Preparation for the US journey starts around six months before the competition date but the hotel base at competition area is not well developed. The nearby location of Capitol Reef NP and Arches NP, annually visited by over 2.5 million people, is one of the reasons why preparations have to be started so far ahead of the trip. Despite the competition taking place near Hankville, the nearest towns of Torrey and Green River form a good hotel base but are located over $80 \mathrm{~km}$ from URC, as shown on Fig. 7. Here there are several motels, a restaurant and small shops. The long distances which have to be made by a team to get to the competition site are an opportunity to choose better accommodation for both competition and tourist activities. Further criteria include price, distance from main communication route and internet access.

The period directly before the competition is used for re-assembly and testing the construction, usually at the accommodation. Tourist activities are only short trips to places located near the motel, maybe a dozen or so kilometers away and taking around 2-3 hours.

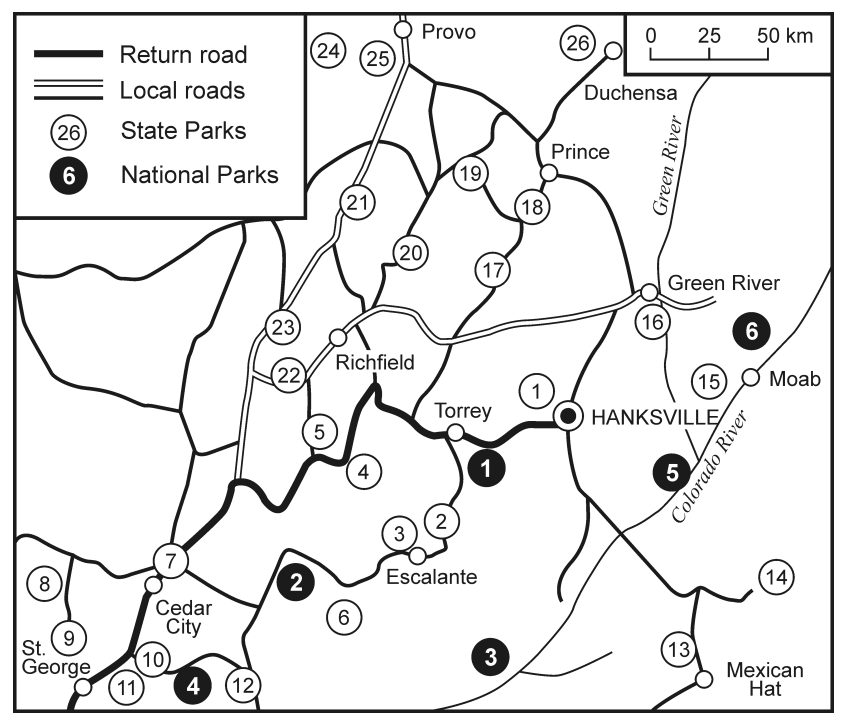

Fig. 8. State parks and National Parks near to the return route - Hanksville

1 - return road; 2 - local roads; 3 - State Parks (1 - Goblin Valley, 2 - Museum Anasazi, 3 - Las Escalante Petrified, 4 - Otter Creek, 5 - Piute, 6 - Kodachrome Basin, 7 - Frontier Homestead, 8 - Gunlock, 9 - Snow Canyon, 10 - Quail Creek, 11 - Sand Hollow, 12 - Coral Pink Sand Dunes, 13 - Goosenecks, 14 - Edge of the Cedars, 15 - Dead Horse Point, 16 - Green River, 17 - Mill site, 18 - Huntington, 19 - Scofield, 20 - Palisade, 21 - Yuba, 22 - Fremont Indian, 23 - Territorial Statehouse, 24 - Camp Floyd, 25 - Utah Lake, 26 - Starvation); 4 - National Parks (1 - Capitol

Reef, 2 - Canyon, 3 - Glen Canyon, 4 - Zion, 5 - Canyonlands, 6 - Arches)

Source: B. PRETTYMAN (2017), http:/ / utah.com/, http://www.visitutah.com/ 


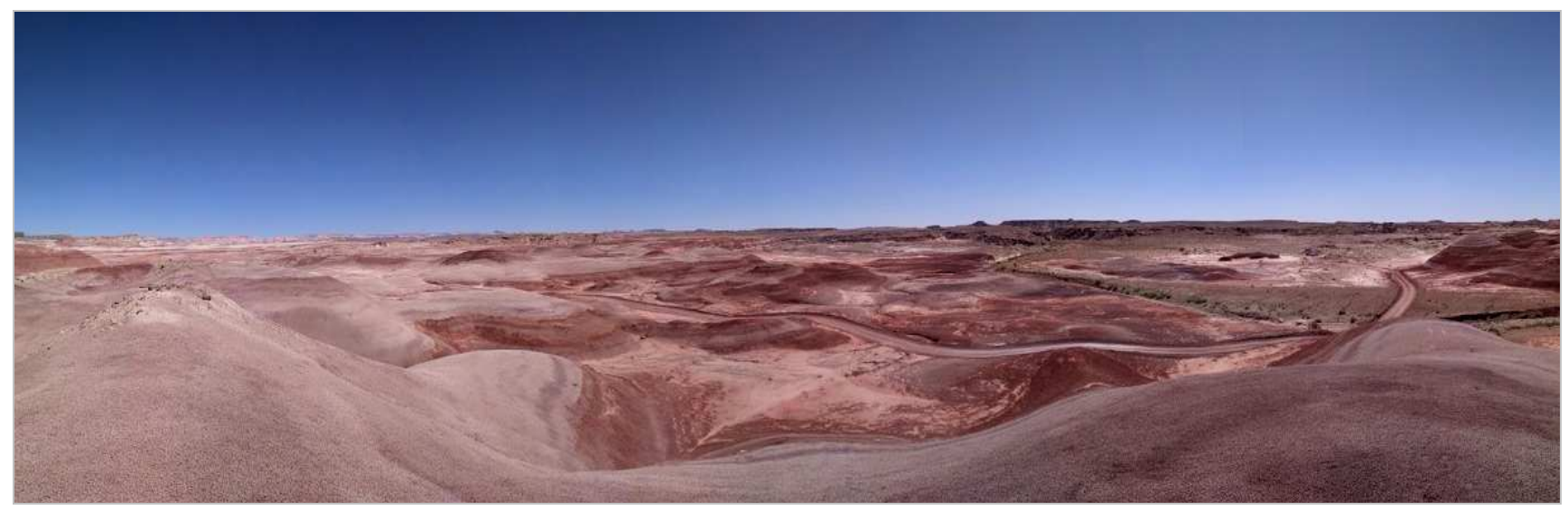

Photo 2. Competition area - the desert in Utah state Source: photo B. Cybulski (2017)

Destinations include the nearest national parks e.g. Capitol Reef NP or Arches NP. An additional form of tourist activity are robot testings on unsurfaced tracks which give an opportunity to better understand the neighborhood and places not in guidebooks.

During the three days of competition participant teams have to perform four off-road tasks/missions. Due to teams spending most of their time in the desert close to the competition site, time which could be used for traveling is limited to an absolute minimum, only for visiting attractions close to the Mares Desert Research Station (Fig. 7).

It seems that the competition site is not attractive for tourists, but the landscape is very immersive. Especially the contrast of the sandstone or siltstone outliers with the flat areas (Photo 2). Additionally, $3 \mathrm{~km}$ from MDRS, is Dino Park (dinosaur excavation), which may be visited between competition tasks, as is Goblin Valley.

The return journey gives the biggest tourist potential. As mentioned before, tourist opportunities depend on the length of a trip, so indirectly on finances. Within one day of the competition site are nine large tourist attractions, especially interesting seem to be the southern part of Utah and the northern part of Arizona. Here are the Grand Canyon, Antelope Canyon, Bryce NP, Zion NP, Horseshoe Bend and Monument Valley, and to visit all those attractions around 3-4 additional days are needed (Fig. 8).

Often the Raptors team meet teams from other countries while sightseeing. The tourist trend, created thanks to the competitions, the authors propose to call "competition tourism". This refer to participation where the period of the competition trip includes tourist elements. Firstly, the teams choose tourist locations very close to the main communication route connecting the accommodation and the competition site. In the case of the USA this is a range of $20-50 \mathrm{~km}$ from the main road, in Poland 5-10 km. Another option are short tourist trips around the accommodation base in a range of 50-100 km (in Poland 10-50 km). Competition tourism may be divided into two types: domestic and international.

\section{SUMMARY}

This work has aimed to analyze new travel trends among students concerning participation in international robotic competitions. In order to provide a comprehensive approach, unidentified in any other academic article, the authors have constructed a special database. Statistics from the websites of competition organizers and the websites of robotics teams from around the world were used. Detail was obtained thanks to a method of in-depth interviews with members of one Polish team, the Raptors.

International robotics competitions allow validation of the technology developed. For students, participation in them is a reward for the effort put in to preparing the robots. Students broaden their knowledge, develop interpersonal skills, and exchange ideas with other students. Two major competitions in the field of robotics - the University Rover Challenge and the European Rover Challenge - were analyzed in this work.

In the URC competition over the years, 106 teams from 10 countries (excluding the USA) have taken part, while in the ERC competition - 30 teams from 12 countries (without Poland). For competition tourism, the visa policy of the state in which the given competition takes place, plays a large role. Despite the necessity of having a visa for the USA by students, for example, from Poland, India, Bangladesh, and the long distances between these countries, in terms of 
the number of teams, Poland is second (after the USA), while India and Bangladesh are in fourth and fifth places respectively. In the case of the ERC competition, despite less rigorous regulations in the EU, individual teams from member states took part in these competitions.

An inseparable element of student academic travel is the tourist aspect. Students do not always have the opportunity to travel abroad, especially on intercontinental trips, so a journey to a competition creates a unique occasion to see its tourist attractions despite the fact that it is not the main purpose. The most important element is finance. As the analysis shows short trips are unprofitable, and a slight increase in travel time changes the total travel costs very little. The URC competition is the background for analyzes that are related to tourist aspects. The URC competition takes place in the middle of the desert in the state of Utah in the NASA Simulated Martian Base (MDRS). The location of the accommodation facilities in relation to the MDRS requires frequent movement creating new opportunities for visiting local tourist attractions.

The authors have observed a new trend among student journeys: 'competition tourism'. Two types were distinguished: national competition tourism and international competition tourism.

\section{BIBLIOGRAPHY}

HUT P., JAROSZEWSKA E., 2011, Studenci zagraniczni w Polsce na tle migracji edukacyjnych na świecie, Instytut Spraw Publicznych, Warszawa.
Michael I., ARMSTRONG A., King B., 2003, The travel behavior of international students: The relationship between studying abroad and their choice of tourist destinations, Journal of Vacation Marketing, 10 (1), pp. 57-66.

MIŃSKI R., 2017, Wywiad pogłębiony jako technika badawcza. Możliwości wykorzystania IDI w badaniach ewaluacyjnych, Przegląd Socjologii Jakościowej, XIII, 3, pp. 30-51.

OKÓLSKI M., 2017, Nowa, krucha mapa europejskich migracji, Studia Migracyjne - Przeglad Polonijny, 1 (163), pp. 5-28.

PRETTYMAN B., 2017, The Utah travel guide. Life elevated, Utah Office of Tourism, Film and Global Branding.

Raport. Kobiety na politechnikach 2007-2017, 2017, Fundacja Edukacyjna „Perspektywy”, marzec.

RÓŻYCKI P., KRUCZEK Z., 2017, Turystyka kosmiczna: historia i przyszłość oraz jej miejsce $\mathrm{w}$ typologii turystyki kulturowej, [in:] S. Owsianowska, R. Winiarski (eds.), Antropologia turystyki, ser. Monografia, 35, pp. 173-189.

RÓŻYCKI P., WYSOCZYŃSKA B., 2011, Space tourism - a twentyfirst century phenomenon, New Problems of Tourism, 1 (4).

Szkoty wyższe $i$ ich finanse w 2015 roku, 2016, GUS, Warszawa.

VARASTEH H., MARZUKI A., RASOOLIMANESH S.M., 2014, Factors affecting international student's Ravel behaviour, Journal of Vacation Marketing, 21 (2), pp. 1-19.

http://roverchallenge.eu/pl/home/; 29.11.2018.

http://roverchallenge.eu/pl/o-erc/; 29.11.2018.

http://urc.marssociety.org/; 29.11.2018.

http://utah.com/; 30.11.2018.

http://worldrobotsummit.org/en/; 29.11.2018.

http://www.visitutah.com/; 30.11.2018.

https://en.wikipedia.org/wiki/Mars_Society; 29.11.2018.

https://irma.nps.gov; 30.11.2018.

https:// pl.usembassy.gov; 25.11.2018.

https://www.eu-robotics.net/robotics_league/about/the-euro pean-robotics-league/index.html; 29.11.2018.

https:// www.indianroverchallenge.in/; 29.11.2018.

https://www.mbzirc.com/; 29.11.2018.

www.factfinder.census.gov; 25.11.2018.

www.tripsavvy.com; 25.11.2018.

www.statista.com; 25.11.2018.

www.booking.com; 25.11.2018.
Article received:

21 September 2018 Accepted: 